Jurnal Ilmiah ESAI Volume 13, No. 1, Januari 2019

p-ISSN 1978-6034 e-ISSN 2580-4944

Impact of Tax Amnesty and Modern Administration System on Taxpayer Compliance

\title{
Dampak Amnesti Pajak dan Sistem Administrasi Modern terhadap Kepatuhan Wajib Pajak
}

Sri Risma Yenny ${ }^{1)}$, Pulung Wicaksono ${ }^{2)}$

1,2) Program Studi Akuntansi, STIE Prasetiya Mandiri Lampung

email: sri.risma.yenny@gmail.com

\begin{abstract}
The purpose of this study is to find empirical evidence of the impact of tax amnesty and the modern administration system on taxpayer compliance on individual taxpayers in Lampung Province. The object chosen is the taxpayers having NPWP in Lampung Province. The data used are primary data obtained by distributing questionnaires to respondents and processed with Likert scale. The samples in this study were 114 people taken randomly. This research is a quantitative research with warpPLS 3.0 test equipment to process data obtained from questionnaires. The results of the study show that tax amnesty as well as the modern administration system has a significant effect on taxpayer compliance.
\end{abstract}

Keywords: Tax Amnesty, Modern Administration System, Taxpayer Compliance

\section{Pendahuluan}

Indonesia sebagai Negara berkembang, saat ini $2 / 3$ penghasilan negara $70 \%$ lebih di yang diperoleh dari media online saibumi.com bahwa realisasi penerimaan pajak yang diterima Direktorat Jenderal Pajak (DJP) Kantor Wilayah Bengkulu dan Lampung tanggal 31 Desember 2016 data realisasi dan target penerimaan pajak disajikan sebagai berikut:peroleh dari pajak, sisanya didapat dari non pajak. Pada tahun 2015 penerimaan dari sektor pajak di provinsi Lampung terus meningkat dari tahun ke tahun, namun belum mencapai target yang ditetapkan. Berdasarkan informasi informasi yang diperoleh dari media on line saibumi.com bahwa realisasi penerimaan pajak yang diterima Direktorat Jenderal Pajak (DJP) Kantor Wilayah Bengkulu dan Lampung tanggal 31 Desember 2016 data realisasi dan target penerimaan pajak disajikan sebagai berikut:

Tabel 1. Penerimaan Pajak DJP Bengkulu Lampung Tahun 2015-2016 (dalam triliun Rp)

\begin{tabular}{lllll}
\hline No & Tahun & Realisasi & Target & Pencapaian \\
\hline 1. & 2015 & 6,898 & 8,861 & $77,89 \%$ \\
2. & 2016 & 7,8 & 9,9 & $78,79 \%$ \\
\hline
\end{tabular}

Sumber: DJP Bengkulu- Lampung

Tabel 1 menunjukkan masih rendahnya tingkat kepatuhan wajib pajak. Beberapa upaya dilakukan pemerintah untuk meningkatkan kepatuhan wajib pajak, diantaranya dengan memberlakukan kebijakan amnesti pajak yang telah disahkan oleh Presiden RI dalam Undang-Undang Amnesti pajak Nomor 11 Tahun 2016 entang Pengampunan Pajak pada tanggal 1 Juli 2016. 
Berikut ini alasan mengapa Indonesia perlu memberikan amnesti pajak kepada para pembayar pajak, antara lain: 1) adanya harta miliki warga Negara baik di dalam maupun di luar negeri yang belum seluruhnya dilaporkan dalam Surat Pemberitahuan Tahunan Pajak Penghasilan; 2) amnesti pajak digunakan untuk meningkatkan penerima negara dan pertumbuhan perekonomian serta kesadaran dan kepatuhan masyarakat dalam pelaksanaan kewajiban Perpajakan, dan perlu menerbitkan Kebijakan pengampunan dan 3) adanya kasus Panama Papper.

Pemerintah mengharapkan para pengusaha yang memiliki banyak aset di luar negeri akan memindahkan asetnya ke dalam negeri (Indonesia), dengan begitu jika banyak pengusaha yang memindahkan asetnya otomatis dapat meningkatkan pendapatan pajak negara. Peraturan ini dikhususkan bagi para pengusaha yang memiliki asset di luar negeri. Untuk para wajib pajak di dalam negeripun, akan diberikan pengampunan pajak. Terutama untuk mereka yang selama ini laporannya tidak benardan cenderung mengabaikan atau tidak tahu tentang pajak usahanya, sekarang inilah saat yang tepat untuk memulainya. Beberapa masalah kepatuhan yang di hadapkan pada era keterbukaan informasi terkait dengan automatic exchange of taxs information (AEOI) dimulai implementasi September tahun 2018. Berkenaan dengan kepatuhan wajib pajak sekitar 250 juta wajib pajak di Indonesia hanya 50 juta yang mempunyai Nomor Pokok Wajib Pajak. Kepatuhan wajib pajak menurut Arum (2012), baik berkenaan dengan kesadaran wajib pajak, otoritas pajak layanan atau pun sanksi perpajakan memiliki dampak positif dan signifikan terhadap kepatuhan wajib pajak.

Selain amnesti pajak, peningkatan Pelayanan juga diperlukan agar wajib pajak memperoleh pelayanan yang lebih baik karena didukung oleh pegawai yang profesional. Selian itu, jika wajib pajak mengalami masalah perpajakan dapat diselesaikan secara lebih cepat sehingga kepastian hukum lebih terjamin dan pelaksanaan ketentuan perpajakan dapat berjalan sesuai prinsipprinsip good governance. Sistem administrasi pada kantor modern menggunakan teknologi informasi sehingga meningkatkan efisiensi. Fasilitas yang dapat digunakan untuk wajib pajak diantaranya e-Registration untuk mendaftarkan dirisebagai wajib pajak, e-SPT untuk aplikasi laporan, dan e-filing untuk penyampaian SPT melalui system online dan real time.

Penelitian ini bertujuan untuk melihat seberapa besar dampak amnesti pajak dan sistem administrasi perpajakan modern terhadap kepatuhan wajib pajak. Penelitian ini penting untuk menemukan bukti empiris dari kebijakan amnesti pajak dan reformasi Sistem administrasi modern dibidang perpajakan benar-benar berpengaruh dalam meningkatkan kepatuhan wajib pajak.

\section{Kajian Literatur dan Pegembangan Hipotesis Amnesti pajak Berpengaruh terhadap Kepatuhan Wajib Pajak}

Amnesti pajak merupakan kebijakan Pemerintah yang tujuannya adalah repatriasi atau menarik dana warga Negara 
Indonesia yang ada di luar negeri, untuk meningkatkan pertumbuhan nasional, meningkatkan basis perpajakan nasional, yaitu asset yang disampaikan dalam permohonan pengampunan pajak dapat dimanfaatkan untuk pemajakan yang akan datang,dan untuk meningkatkan penerimaan pajak tahun ini. Melalui amnesty pajak ini diharapkan dapat meningkatkan kepatuhan wajib pajak yang selama ini belum mematuhi kewajibannya.

Beberapa penelitian tentang amnesti pajak, di antaranya penelitian yang dilakukan oleh Mahestyanti, dkk (2018). Hasil penelitian Mahestyanti menunjukkan bahwa wajib pajak dengan kekayaan tinggi memiliki tingkat kepatuhan yang rendah dan wajib pajak lebih menyukai untuk mengikuti amnesty pajak pada tingkat tariff terendah yakni pada $2 \%$. Studi lain mengenai kepatuhan wajib pajak menyimpulkan bahwa kesadaran, sanksi pajak dan kualitas jasa otoritas pajak tidak berpengaruh terhadap kepatuhan wajib pajak karena masih kurangnya sosialisasi tentang aturan kepada wajib pajak. (Handayani,Ucik dan Laily,2017). Penelitian yang dilakukan di Rusia menunjukkan bahwa pelaksanaan amnesty pajak memiliki sedikit dampak jangka pendek atau panjang terhadap pendapatan (Casal,Sandroetal,2016). Hasil penelitian Ngadiman dan Huslin (2015), mengatakan bahwa tingkat kepatuhan wajib pajak dapat dipengaruhi oleh amnesty pajak. Berdasarkan hasil penelitian ada terlihat belum konsisten. Oleh karena itu hipotesis yang di ambil dalam penelitian kali ini adalah;
H1: Amnesti pajak berpengaruh signifikan terhadap kepatuhan wajib pajak.

\section{Sistem Administrasi Modern Berdampak Signifikan Terhadap Kepatuhan Wajib Pajak}

Layanan kepada wajib pajak merupakan salah satu faktor yang dapat meningkatkan kepatuhan wajib pajak dalam melaksanakan kewajibannya. Wajib pajak tidak perlu antri lama untuk membayar pajak bahkan dapat dilakukan secara online, hal ini berarti sudah menggunakan sistem administrasi yang modern. Penelitian yang dilakukan oleh Aryati,dkk (2015), menunjukkan bahwa kesadaran Wajib Pajak memiliki peran mediasi penuh dalam hubungan antara kemanfaatan pajak, kualitas layanan, dan kepatuhan wajib pajak. Hasil penelitian Irmayani (2015), menyatakan bahwa modernisasi sistem administrasi perpajakan memiliki dampak terhadap wajib pajak.

H2: Sistem Administrasi modern berpengaruh signifikan terhadap kepatuhan wajib pajak.

\section{Metode Penelitian}

Penelitian ini menggunakan metode kuantitatif. Populasi pada penelitian ini adalah seluruh wajib pajak di Provinsi Lampung, sedangkan sampel diambil secara random. Responden diminta mengisi kuesioner dengan skala likert. Kemudian data diolah dengan menggunakan WarpPLS 3.0, Sebelum kuesioner disebar, terlebih dahulu penulis melakukan pilot study. Adapun, tujuan dilakukan pilot study adalah untuk 
menghindari ketidak mengertian responden dalam memahami setiap pertanyaan serta untuk menguji tingkat validitas dan reliabilitas kuesioner. Sehingga kuesioner layak untuk disebar. Pilot study ini dilakukan dengan menyebar 20 kuesioner kepada wajib pajak yang bukan responden.

\section{Hasil Dan Pembahasan}

\section{a. Deskripsi Data dan Responden}

Kuesioner yang disebar kepada responden dalam penelitian ini sebanyak 130 eksemplar kepada wajib pajak yang berada di kota Bandar Lampung, kabupaten Metro, Lampung Barat, Way Kanan, Lampung Tengah, Lampung Timur, Pringsewu, Lampung Selatan, dan Tulang Bawang. Kuesioner yang kembali sebanyak 118 eksemplar, dan dapat diolah sebanyak 114 eksemplar, dangan rincian sebagai berikut:

Tabel 2. Data Sebaran Kuesioner

\begin{tabular}{llllll}
\hline & & Disebar & Kembali & Dapat diolah & $10 \%$ \\
\hline 1. & Bandar Lampung & 15 & 13 & 13 & $15 \%$ \\
2. & Metro & 20 & 20 & 20 & 12 \\
3. & Lampung Barat & 15 & 15 & 15 & 12 \\
4. & Lampung Tengah & 19 & 18 & 18 & 14 \\
5. & Waykanan & 21 & 20 & 20 & 2 \\
6. & Pringsewu & 5 & 5 & 3 & 3 \\
7. & Tanggumus & 5 & 5 & 4 & 10 \\
8. & Lampung Selatan & 15 & 13 & 13 & 4 \\
9. & Lampung Timur & 5 & 5 & 5 & 2 \\
10 & Lampung Utara & 5 & 3 & 3 & $84 \%$ \\
11. & Tulang bawang Barat & 5 & 0 & 0 & 114 \\
\hline
\end{tabular}

Sumber:Data diolah oleh peneliti (2018)

Sebanyak 56\% responden berjumlah laki-laki, dengan tingkat pendidikan rata-rata diploma dan sarjana. Selain itu lebih dari dari sebagian responden masih berusia 30 tahun ke bawah. Dengan demikian responden dalam penelitian ini relatif berimbang antara laki-laki dengan wanita, dimana usia mereka masih relatif muda dan terdidik.

\section{b. Analisis Data}

Variabel amnesti pajak memiliki tiga indikator, sedangkan sistem administrasi modern memiliki sebelas indikator, dan sembilan indikator untuk kepatuhan wajib pajak.

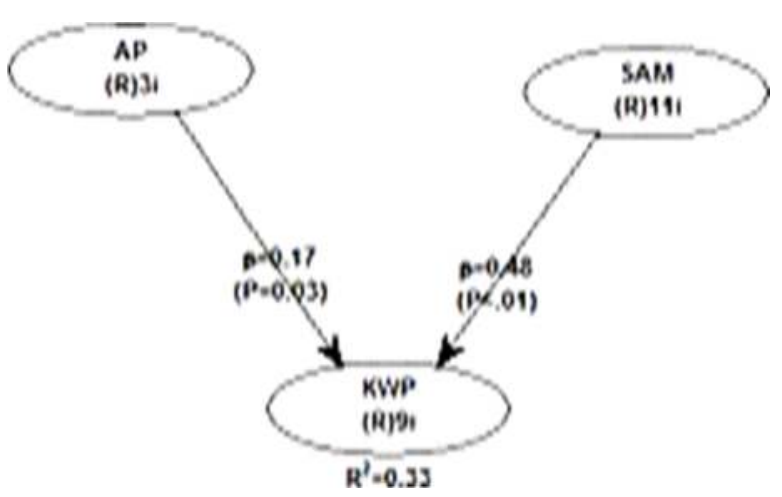

Sumber: WarpPLS 3.0 (2018)

Gambar 1. Hasil Pengujian Model

Hasil pengujian validitas konvergen dari instrumen pengukuran (kuesioner) dapat dilihat dari output combined loadings and cross-loadings.sering. Validitas konvergen sering disebut outer model atau confirmatory factor analysis (CFA). Ada dua kreteria untuk 
menilai apakah outer model memenuhi syarat validitas konvergen utnuk konstruk reflektif, yaitu loading factor harus diatas 0,70 karena variabel laten seharusnya minimal dapat menjelaskan variansi setiap inikator sebesar $50 \%$ (hasil dari $0,7^{2}$ mendekati $50 \%$ ) dan nilai
P signifikan $(<0,05)$. Namun demikian loading antara 0,40-0,70 harus tetap dipertimbangkan untuk dipertahankan, terutama untuk kuesioner yang baru dikembangkan (Hair dkk dalam Sholihin dan Ratmono, 2013).

Tabel 3. Output Combined Loading and Cross Loading.

\begin{tabular}{lllllll}
\hline & AP & SAM & KWP & TYPE & SE & PValue \\
\hline AP1 & 0.746 & 0.005 & 0.056 & Reflective & 0.077 & $<0.001$ \\
AP2 & 0.778 & -0.026 & -0.091 & Reflective & 0.077 & $<0.001$ \\
AP3 & 0.755 & 0.022 & 0.038 & Reflective & 0.077 & $<0.001$ \\
SAM1 & -0.209 & 0.623 & 0.138 & Reflective & 0.080 & $<0.001$ \\
SAM2 & -0.401 & 0.646 & 0.266 & Reflective & 0.079 & $<0.001$ \\
SAM3 & -0.465 & 0.618 & 0.183 & Reflective & 0.080 & $<0.001$ \\
SAM4 & 0.293 & 0.389 & 0.133 & Reflective & 0.085 & $<0.001$ \\
SAM5 & 0.142 & 0.611 & -0.195 & Reflective & 0.080 & $<0.001$ \\
SAM6 & 0.106 & 0.579 & -0.133 & Reflective & 0.081 & $<0.001$ \\
SAM7 & 0.259 & 0.650 & -0.022 & Reflective & 0.079 & $<0.001$ \\
SAM8 & -0.139 & 0.638 & 0.177 & Reflective & 0.080 & $<0.001$ \\
SAM9 & 0.109 & 0.669 & -0.087 & Reflective & 0.079 & $<0.001$ \\
SAM10 & 0.168 & 0.766 & -0.059 & Reflective & 0.077 & $<0.001$ \\
SAM11 & 0.178 & 0.742 & -0.298 & Reflective & 0.078 & $<0.001$ \\
KWP1 & 0.176 & 0.248 & 0.591 & Reflective & 0.081 & $<0.001$ \\
KWP2 & 0.228 & -0.220 & 0.676 & Reflective & 0.079 & $<0.001$ \\
KWP3 & -0.157 & -0.112 & 0.794 & Reflective & 0.077 & $<0.001$ \\
KWP4 & -0.209 & -0.009 & 0.813 & Reflective & 0.076 & $<0.001$ \\
KWP5 & -0.144 & 0.185 & 0.822 & Reflective & 0.076 & $<0.001$ \\
KWP6 & 0.079 & 0.330 & 0.489 & Reflective & 0.083 & $<0.001$ \\
KWP7 & -0.101 & -0.160 & 0.696 & Reflective & 0.078 & $<0.001$ \\
KWP8 & 0.163 & -0.042 & 0.638 & Reflective & 0.080 & $<0.001$ \\
KWP9 & 0.115 & -0.109 & 0.709 & Reflective & 0.078 & $<0.001$ \\
\hline SWmb & & & & &
\end{tabular}

Sumber: WarpPLS3.0 (2018)

Tabel diatas menunjukkan semua loading di atas $0,4-0,7$ dengan $\mathrm{P}<0,001$, hal ini berarti semua variabel valid. Kontibusi linier dari setiap indikator dapat dilihat pada output indicator weight. Setiap skor variabel laten dihitung sebagai sebuah kontribusi linier dari indikator- indikatornya. Kreteria yang harus dipenuhi adalah bobot (weight) harus signifikan, dimana $\mathrm{P}<0,05$, dan nilai VIF kurang dari 3,3 (Kock dalam Sholihin dan Ratmono, 2013). Namun demikian menurut
Hair dkk dalam Sholihin dan Ratmono (2013), peneliti harus hati-hati untuk menghapus indikator formatif karena akan mempengaruhi isi secara keseluruhan. Jika loading bernilai diatas 0,50 meskipun indikator weight tidak signifikan, peneliti dapat mempertahankannya. Apabila outer loading di bawah 0,50 namun signifikan, maka peneliti harus mempertimnangkan dari relevansi teoritis. Jika dihapus akan mempengaruhi isi konstruk sebaiknya dipertahankan. 
Tabel 4. Output Indicator Weight

\begin{tabular}{lrrrrrr}
\hline & AP & SAM & KWP & SE & PValue & VIF \\
\hline AP1 & 0.431 & 0.000 & 0.000 & 0.084 & $<0.001$ & 1.225 \\
AP2 & 0.449 & 0.000 & 0.000 & 0.084 & $<0.001$ & 1.273 \\
AP3 & 0.436 & 0.000 & 0.000 & 0.084 & $<0.001$ & 1.238 \\
SAM1 & 0.000 & 0.140 & 0.000 & 0.090 & 0.063 & 1.696 \\
SAM2 & 0.000 & 0.145 & 0.000 & 0.090 & 0.056 & 2.709 \\
SAM3 & 0.000 & 0.138 & 0.000 & 0.090 & 0.064 & 2.473 \\
SAM4 & 0.000 & 0.087 & 0.000 & 0.092 & 0.171 & 1.282 \\
SAM5 & 0.000 & 0.137 & 0.000 & 0.090 & 0.066 & 1.938 \\
SAM7 & 0.000 & 0.146 & 0.000 & 0.090 & 0.055 & 2.044 \\
SAM8 & 0.000 & 0.143 & 0.000 & 0.090 & 0.058 & 1.641 \\
SAM9 & 0.000 & 0.150 & 0.000 & 0.090 & 0.050 & 2.109 \\
SAM10 & 0.000 & 0.172 & 0.000 & 0.090 & 0.029 & 3.901 \\
SAM11 & 0.000 & 0.166 & 0.000 & 0.090 & 0.033 & 3.153 \\
KWP1 & 0.000 & 0.000 & 0.134 & 0.091 & 0.070 & 1.504 \\
KWP2 & 0.000 & 0.000 & 0.153 & 0.090 & 0.046 & 1.831 \\
KWP3 & 0.000 & 0.000 & 1.180 & 0.089 & 0.023 & 2.409 \\
KWP4 & 0.000 & 0.000 & 1,184 & 0.089 & 0.021 & 3.311 \\
KWP5 & 0.000 & 0.000 & 0.187 & 0.089 & 0.020 & 3.383 \\
KWP6 & 0.000 & 0.000 & 0.111 & 0.091 & 0.112 & 1.379 \\
KWP7 & 0.000 & 0.000 & 0.158 & 0.090 & 0.041 & 1.747 \\
KWP8 & 0.000 & 0.000 & 0.145 & 0.090 & 0.056 & 1.611 \\
KWP9 & 0.000 & 0.000 & 0.161 & 0.090 & 0.038 & 1.951 \\
\hline SW6 W $953.0(2018)$ & & & & &
\end{tabular}

Sumber: WarpPLS3.0 (2018)

Tabel 5 di bawah ini adalah output laten variable coefficients yang memuat beberapa informasi, diantaranya $R$-squared .

Tabel 5. Output Laten Variable Coefficients

\begin{tabular}{lrrr}
\hline & \multicolumn{1}{c}{ AP } & \multicolumn{1}{c}{ SAM } & \multicolumn{1}{c}{ KWP } \\
\hline R-squared & & & 0.331 \\
Adj. R-squared & & & 0.319 \\
Composite reliab & 0.804 & 0.880 & 0.894 \\
Cronbach's alpha & 0.633 & 0.894 & 0.865 \\
Avg. var. extrac. & 0.577 & 0.405 & 0.490 \\
Full Collin. VIF & 1.259 & 1.542 & 1.417 \\
Q-squared & & & 0.345 \\
Min & -1.669 & -4.065 & -4.383 \\
Max & 1.909 & 2.116 & 2.322 \\
Median & 0.108 & -0.196 & -0.033 \\
Mode & -0.734 & -0.433 & -0.033 \\
Skewness & 0.804 & -0.524 & -0.496 \\
Exc. kurtoris & -0.370 & 2.930 & 3.105 \\
\hline Sumber: WarpPLS3.0(2018) & &
\end{tabular}

Sumber: WarpPLS3.0(2018)

R-squared 0,331menunjukkan bahwa varian Kepatuhan WajibPajak dapat dijelaskan sebesar 33\% (pembulatan) oleh varian Amnesti Pajak dan Sistem Administrasi Modern. Q-squared digunakan untuk penilaian validitas prediktif atau

relevansi dari sekumpulan variable laten predictor pada variabel kriterion.Q-squared harus di atas nol.Pada penelitian ini $Q$ squared bernilai 0,345 ,hal ini menunjukkan validitas prediktif yang baik. 
Ukuran reliabilitas instrumen dapat dilihat pada composite reliability dan cronbach'salpha yang harus mempunyai nilai di atas 0,7. Pada penelitian ini compositereliability dan cronbach'salpha bernilai diatas 0,7.Selain itu untuk melihat hasi lpengujian kolinearitas dapat dilihat pada nilai full collinearity VIF yang nilainya kurang dari 3,3. Hasil olahdata menunjukkan nilai full collinearity VIF adalah 1,259,1,542, dan 1,417 , artinya model bebas dari masalah kolinearitas vertikal, lateral, dan comman method bias.

Output correlations among latent variables digunakan untuk melihat koefisien korelasi antarvariabel laten, serta untuk mengevaluasi validitas diskriminan instrumen penelitian. AVE dari satu variabel harus lebih tinggi dari korelasi antarvariabel lain, seperti yang dapat dilihat dari tabel 6. Berdasarkan tabel tersebut dapat diketahui nilai AVE dari masing-masing variabel lebih tinggi jika dibandingkan dengan variabel lainnya.

\section{Kesimpulan, Saran dan Implikasi Diskusi dan Batasan}

Kebijakan amnesti pajak yang diberlakukan oleh pemerintah adalah untuk repatriasi atau menarik dana WNI yang ada di luar negeri, yang kemudian dana tersebut diharapkan dapat meningkatkan pertumbuhan ekonomi nasional, menjadi sumber pajak untuk periode berikutnya, dan tentu saja untuk meningkatkan pendapatan saat ini dari sisi pajak. Bukan hanya di Indonesia, ada 13 negar lain juga yang menerapkan kebijakan amnesti pajak ini, seperti Korea Selatan, Thailand, Fiji,
Argentina, Pakistan, dan Gibraltar. Di sisi lain, dengan diperbaikinya sistem administrasi, menggunakan sistem yang lebih modern, diharapkan tujuan dari pemerintah untuk meningkatkan pemasukan kas negara dari pajak sesuai dengan target dapat terealisasi.

Secara keseluruhan penelitian ini, tujuan untuk menjawab pertanyaan penelitian: apakah amnesti pajak dan sistem administrasi modern dapat meningkatkan kepatuhan wajib pajak. Penulis melakukan survey kepada wajib pajak yang berada di Provinsi Lampung. Data yang berhasil terkumpul sebanyak 114 kuesioner. Data tersebut kemudian kami uji dengan menggunakan WarpPLS 3.0

Pada model pengukuran, kami melakukan uji untuk mengetahui tingkat validitas dan reabilitas konstruk. metode: validitas konvergen dan validitas diskriminan digunakan untuk menguji tingkat validitas. Validitas diskriminan dianalisa dengan menggunakan cross-loading. Sedangkan untuk menguji Reliabilitas dari suatu konstruk mengunakan cronbach's alpha dan composite reliability. Berdasarkan hasil uji reliabilitas, semua konstruk dianggap memadai.

Selanjutnya kami menguji semua hipotesis menggunakan WarpPLS 3.0. Hasil pengujian menunjukkan semua hipotesis terdukung, sehingga dapat disimpulkan bahwa amnesti pajak dan sistem administrasi modern mempunyai dampak yang signifikan dalam meningkatkan kepatuhan wajib pajak.

\section{Batasan dan untuk Penelitian Selanjutnya}

Penelitian in masih belum sempurna, masih ada kekurangan dan keterbatasan, 
diantaranya: Responden dalam penelitian ini wajib pajak yang dilakukan secara acak yang berjumlah 114 responden. Untuk penelitian selanjutnya jumlah sampel sebaiknya diperbanyak lagi, agar jangkauan dan sebaran sampel lebih merata. Selain itu penelitian ini hanya menguji dua variabel bebas yang mempengaruhi kepatuhan wajib pajak. Perlu dilakukan ekplorasi faktor-faktor lainnya yang juga berpengaruh terhadap kepatuhan wajib pajak di era digital saat ini. Penelitian selanjutnya juga dapat menambahkan metode wawancara untuk menyempurnakan hasil penelitiannya.

\section{Implikasi}

Hasil empiris dari penelitian ini diharapkan dapat menjadi bahan masukan dan evaluasi bagi pemerintah pada umumnya dan Direktorat Jendral Pajak pada khususnya dalam mengambil kebijakan dan dalam memperbaiki sistem layanan berbasis teknologi untuk wajib pajak.

\section{Daftar Pustaka}

\section{Jurnal}

Andreoni, James; Erard, Brian; Feinstein, Jonathan. Tax Compliance. 1998. Journal of Economic Literature, Vol. 36 No. 2 (Jun 1998). Pp. 818-860.

Alm, James \& Beck, William. 1993. Tax Amnesties And Compliance In The Long Run: A Time Series Analysis. National Tax Journal, Vol. 46 No.1 (March 1993). Pp 53-60.

Alm, James; Vazquez, Jorge Martinezn, and Wallace, Sally. 2009. Do Tax Amnesties Work? The Revenue Effects of Tax Amnesties During the Transition in the Russian Federation. Economic Analysis \& Policy, Vol. 39 No. 2: USA.
Arifin, Aditya Febriyan. 2015. Pengaruh Modernisasi Sistem Administrasi Perpajakan, Kesadaran Perpajakan, Sanksi Pajak, dan Pelayanan Fiskus Terhadap Kepatuhan Wajib Pajak Orang Pribadi Pada KPP Pratama. Jurnal Akuntansi Vol. 3 No.1

Casal, Sandro; Kogler, Christoph; Mittone, Luigi; Kirchler. Erich. 2016. Tax compliance depends on voice of taxpayers. Journal of Economic Psychology.

Handayani, Ucik; Lail, Nujmatul. 2017, The Influence of Consciousness, Tax Penalty and the Quality of Tax Authorities Service on Tax Complience (Survey on Taxpayer of Boarding House in Lowokwaru District). Journal of Accounting and Business Education), Vol 1, Iss 2, Pp 286-297.

Mahestyanti, Puri; Juanda, Bambang; Anggraeni, Lukytawati. 2018. The Determinants of Tax Compliance in Tax Amnesty Programs: Experimental Approach. Jurnal Etikonomi Volume 17 (1), Pp $93-110$.

Ngadimandan Huslin:Pengaruh Sunset Policy,Amnesti pajak dan Sanksi Pajak terhadap kepatuhan wajib pajak Jurnal Akuntansi/Volume XIX, No. 02, Mei 2015:225-241

\section{Bab dalam Buku}

Nurmantu, Safri. 2010. Pengantar Perpajakan. Jakarta: Granit Peraturan Mentri Keuangan No. 118/PMK.03/2016 Tentang Amnesti Pajak.

Purnomo, Abdi, 2004, Ancaman Paksa Badan Naikkan Setoran Pajak, Tempo Interaktif, 23 Maret 2004

Sholihin,M; dan Ratmono,D. 2013. Analisis SEM-PLS dengan WarpPLS 3.0. Penerbit Andi. Yogyakarta.

Undang-Undang Amnesti pajak Nomor 11 Tahun 2016 Tentang Pengampunan Pajak pada tanggal 1 Juli 2016. 


\section{Skripsi, Tesis, Desertasi}

Arum, Jarijanti Puspa And Zulaikha (2012), Pengaruh Kesadaran Wajib Pajak, Pelayanan fiscus, dan Sangsi Pajak TerhadapKepatuhan Wajib Pajak Orang Pribadi Yang Melakukan Kegiatan Usaha Dan Pekerjaan Bebas (Studi Di Wilayah Kpp Pratama Cilacap. Undergraduate thesis, Fakultas Ekonomika dan Bisnis, Universitas Diponogoro

\section{Publikasi elektronik}

Misbakhun. 2017. Penerimaan Pajak Capai 81 Persen dari Target 2016. Diunduh pada tanggal 17 Juni 2016, pada laman

http://bisnis.liputan6.com/read/269397 9/penerimaan-pajak-capai-81- persendari-target-2016

Sitopu, Saryah M. Menjelang Tutup Tahun, DJP Kanwil Bengkulu - Lampung Terima Setoran Pajak Mencapai Rp6,898 Triliun. Diunduh tanggal 3 Februari 2019 dari laman https:/www.saibumi.com/artikel71375-menjelang-tutup-tahun-djpkanwil-bengkulu--lampung-terimasetoran-pajak-mencapai-rp6898triliun.html 